\title{
ZAGADNIENIE POCHODZENIA IDEI BOGA W UjęCIACH Kartezjusza I J. L. WOlzogena
}

\author{
Paweł Kosiński, pawelkos@gazeta.pl Uniwersytet Wrocławski Pl. Uniwersytecki 1, 50-137 Wrocław
}

\begin{abstract}
STRESZCZenie
Temat artykułu dotyczy koncepcji wrodzoności idei Boga przedstawionej przez René Descartesa i krytyki tego poglądu dokonanej przez Jana Ludwika Wolzogena. Poddałem szczegółowej analizie treść Medytacji o pierwszej filozofii Kartezjusza oraz treść Uwwag do Medytacji Metafizycznych René Descartesa Wolzogena, na tej podstawie dokonałem rekonstrukcji poglądów Wolzogena i Kartezjusza. Niezbędne było również ukazanie kontekstu historycznego rozważań obu filozofów. Kartezjusz twierdził, że idea bytu doskonałego i nieskończonego została umieszczona w umyśle przez Boga. Wolzogen chciał pokazać, że Kartezjusz nie dowiódł wrodzoności tej idei. Uważał, że wszystkie idee pochodzą z doświadczenia zmysłowego i idea Boga została ukształtowana przez umysł. Moim głównym celem było wykazanie, że Wolzogen przyjmował tomistyczny pogląd, zgodnie z którym ludzki umysł dysponuje niedoskonałym pojęciem Boga.
\end{abstract}

Słowa kluczowe: Natywizm kartezjański, Bóg, Umysł, Socynianizm, René Descartes, Jan Ludwik Wolzogen

\section{The issue of the origin of the concept of God: The Views of Descartes and Wolzogen Summary}

\begin{abstract}
My paper concerns René Descartes's conception of innate idea of God and Johann Ludwig von Wolzogen's critique of Descartes's view. I gave a detailed analysis of the content of Meditations on First Philosophy by René Descartes and the content of Obiections to Descartes' Meditations by Wolzogen, and on that basis, I reconstructed Descartes and Wolzogen's views. It was also necessary to show the historical context of both philosophers' ideas. Descartes argued that the idea of a perfect and infinite being was placed in mind by God. Wolzogen wanted to show that Descartes didn't prove the idea of innate God. He believed that all ideas derive from sense experience and the mind generates idea of God. My main purpose was to show that Wolzogen accepted Thomistic's view in which the human mind has imperfect concept of God.

Key words: Cartesian nativism, God, Mind, Socinianism, René Descartes, Johann Ludwig Wolzogen

\section{WSTĘP}

Kluczową rolę w filozofii Kartezjusza odgrywała idea nieskończoności. Francuski filozof dostrzegł, że nie mógłby pomyśleć o żadnej rzeczy skończonej, gdyby nie pojmował idei nieskończoności'. Twierdził, że idea nieskończoności jest pierwotna, a jej negację stanowi idea rzeczy skończonych. Po dokładnej analizie doszedł do wniosku, że idea bytu nieskończonego została zaszczepiona w umyśle przez samego Boga (jest wrodzona umysłowi)². Uważał, że jedynie byt doskonały może być przyczynąi idei nieskończoności.

Poglądy Kartezjusza silnie oddziaływały na kraje zachodnioeuropejskie (Francja, Niderlandy), jednak na terenie XVII wiecznej Rzeczypospolitej filozofia Kartezjusza nie spotkała się z większym zainteresowaniem³. Wyjątek stanowili socynianie, którzy często podróżowali do Francji oraz Holandii i żywo interesowali się nowymi prądami filozoficznymi (nawiązali w tych krajach liczne kontakty z wybitnymi myślicielami, takimi jak Hugo Grocjusz, Marin Mersenne). cynianie zajmowali w większości stanowisko antykartezjańskie, gdyż koncepcje metafizyczne i epistemologiczne Kartezjusza były całkowicie przeciwne ich poglądom ${ }^{5}$. Jednym z najważniejszych socyniańskich krytyków Kartezjusza był Jan Ludwik Wolzogen, który w Uwagach do Medytacji Metafizycznych René Descartesa wykazywat, że idea Boga nie jest wrodzona, lecz jest ukształtowana przez umysł'.

\footnotetext{
1 F. Alquié, Kartezjusz, Warszawa 1989, s. 98.

2 R. Descartes, Medytacje o pierwszej flozofi wraz zarzutami uczonych mężów i odpowiedziami autora oraz rozmowa z Burmanem, T. 1, Warszawa 1958 , s. 67.

3 W. Wasik, Kartezjusz w Polsce, „Przegląd Filozoficzny” 1937, r. 40, z. 2, s. 206.

4 Tamże, s. 206-207. Mianem ,socynianizm” określano oficjalną doktrynę ruchu religijnego Braci Polskich w XVII w., twórcą socynianizmu był włoski myśliciel religijny F. Socyn; zob. Z. Ogonowski, Socynianizm a oświecenie, Warszawa 1966, s. 13.

5 Zob. Tamże, s. 313.

6 J. L. Wolzogen, Uwagi do Medytacji Metafizycznych René Descartes'a, Warszawa 1959, s. 44.
} 
J. L. Wolzogen opierał swą koncepcję na sensualizmie. Uważał, że wszystkie idee mają swe źródło w doświadczeniu zmysłowym i tym samym odrzucał istnienie wiedzy wrodzonej. W poznaniu Boga podkreślał rolę objawienia. Sądził, że człowiek nie mógłby wiedzieć o istnieniu Boga, gdyby nie odbierał wrażeń zmysłowych. Umysł kształtuje ideę Boga dzięki zdolności rozszerzania doskonałości dostrzeżonych w sobie i innych rzeczach, a zatem nie jest to idea przedstawiająca rzeczywisty byt ${ }^{7}$. Twierdzil, że idea utworzona przez umysł nie może być nieskończona, w związku z tym nie jest ideą rzeczywistego Boga i na jej podstawie nie można wnioskować o tym, że Bóg istnieje 8

Głównym powodem, który skłonił J. L. Wolzogena do przedstawienia krytyki koncepcji wrodzoności idei Boga, był fakt, że prezentowany przez Kartezjusza pogląd zagrażał wierze w objawienie. Autor Medytacji o pierwszej filozofii sądzit, że idea Boga nie została utworzona, ponieważ jest doskonała i niczego do niej dodać ani z niej ująćnie można' ${ }^{9}$ Zdaniem J. L. Wolzogena człowiek nie posiada pełnej i doskonałej wiedzy o Bogu i dlatego niejest prawda, że do idei Boga w umyśle niczego już nie można dodać10. Człowiek dzięki objawieniu może dowiedzieć się o wielu wcześniej nieznanych rzeczach dotyczących Boga, a Kartezjusz nie bierze tego faktu w ogóle pod uwagę. Według Wolzogena Kartezjusz nie powinien dowodzić istnienia Boga samym rozumem, gdyż mogło się to wiązać z tym, że rozum z pominięciem Pisma Sw. odnajduje drogę do Boga ${ }^{11}$. Wolzogen obawiał się, że w koncepcji Kartezjusza umysł dochodzi do wiedzy o Bogu o własnych siłach, a przez to objawienie staje się zbędne. Należy zwrócić uwagę na to, że obawy Wolzogena były zasadne, ponieważ poglądy Kartezjusza stały się podstawą dla myślicieli deistycznych negujących objawienie. Kartezjusz oddzielając sferę wiary i wiedzy oraz zastępując teorię świata organicznego przez teorię świata mechanistycznego przyczynił się do tego, że rozum mógł obejść się bez pomocy objawienia ${ }^{12}$.

Dzieło J. L. Wolzogena Uwagi do Medytacji Metafizycznych René Descartesa jest niezwykle ważne dla dorobku polskiej myśli filozoficznej z trzech powodów. Po pierwsze stanowi krytyczną odpowiedź na racjonalizm kartezjański, który był jednym z najważniejszych systemów filozoficznych nowożytnej Europy. Po drugie prezentuje poglądy myśliciela bardzo dobrze obeznanego z ówczesną myślą filozoficzną. J. L. Wolzogen słusznie przewidział, że racjonalizm kartezjański przyczyni się do powstania deizmu. Po trzecie ukazuje, że na terenie XVII wiecznej Polski rozwijała się filozofia nieodbiegająca swym poziomem od ówczesnej filozofii zachodnioeuropejskiej. Z tych właśnie przyczyn zdecydowałem się zestawić ze sobą stanowiska Kartezjusza i J. L. Wolzogena w kwestii pochodzenia idei Boga. W artykule starałem się zwrócić szczególną uwagę na te elementy filozofii Kartezjusza, które mogły w sposób bezpośredni inspirować deistów.

\section{IDEA BYTU NIESKOŃCZONEGO I NIEOGRANICZONOŚCI}

Kartezjusz ujmuje siebie jako podmiot skończony. Zauważa, że wszelkie treści w umyśle również może pojąć jako skończone z wyjątkiem jednej ${ }^{13}$. Idea bytu nieskończonego jest czymś zewnętrznym wobec podmiotu, nie może być sprawiona przez podmiot skończony, ponieważ to przekracza jego możliwości ${ }^{14}$. W Medytacji II stwierdzit, że ujmuje to, co nieskończone za pomocą prawdziwej i pozytywnej idei, tym samym zaprzeczając, że idea ta powstaje poprzez negację skończonego (ujęcie nieskończonego bytu poprzedza ujęcie tego, co skończone) ${ }^{15}$. Kartezjusz uznaje, że to, co nieskończone ma ontologiczne pierwszeństwo przed tym co skończone, gdyż nieskończoność ma wymiar pozytywny, natomiast to, co skończone ma wymiar negatywny (koncepcja ta odegrała kluczową rolę w XVII wiecznym racjonalizmie) ${ }^{16}$. Jego zdaniem ujęcie Boga i ujęcie siebie samego jako skończonego bytu stanowią w rzeczywistości jedno ujęcie, ponieważ mając świadomość własnej skończoności jest się również świadomym własnej ograniczoności w stosunku do Boga ${ }^{17}$.

Przeciwko tej koncepcji występowali przedstawiciele empiryzmu, którzy pojmowali nieskończoność negatywnie, jako zaprzeczenie skończoności. Empirycy przyjmowali, że idea nieskończoności może być utworzona dzięki rozszerzaniu doskonałości pojmowanych przez umysł, np. można przewidzieć, że nieustanne sumowanie kolejnych elementów skoń-

7 Tamże, s. 31-32.

8 Tamże, s. 32

9 L. Chmaj, Wolzogen przeciw Descartes'owi: przyczynek do charakterystyki zwiazku arianizmu polskiego z myśla filozoficzna Zachodu, „Archiwum Komisji do Badania Historii Filozofii w Polsce"1915, T. 1, cz. 1, s. 120.

10 Tamże, s. 120.

11 Tamże, s.92.

12 L. Kołakowski, Iluzje demitologizacji, [w:] Tenże, Moje stuszne poglady na wszystko, Kraków 1999, s. 68.

13 W. Augustyn, Podstawy wiedzy u Descartesa i Malebranche'a, Warszawa 1973, s. 92.

14 Tamże, s. 92.

15 R. Descartes, Odpowiedź na zarzuty drugie, [w:] Tenże, Medytacje... dz. cyt., s. 60.

16 G. Rodis-Lewis, Kartezjusz i racjonalizm, Warszawa 2000, s. 39.

17 F. Alquié, dz. cyt., s. 98. 
czonych nigdy nie będzie miało ostatecznego kresu ${ }^{18}$. Kartezjusz sądzil, że empirycy mylą nieograniczoność z nieskończonościa, ponieważ nieprzerwane sumowanie kolejnych skończonych elementów ukazuje jedynie, że umysł nie może ująć granicy tego ciaggu (jest to ujęcie nieograniczonego), natomiast nieskończoność, to coś absolutnie pozytywnego i doskonałego i do niej nie można już niczego dodaći ${ }^{19}$. Kartezjusz w Odpowiedzi na zarzuty I wyjaśnia, że nieskończoność to coś, co nie ma absolutnie wszelkich granici wyłącznie Bóg może być nieskończony ${ }^{20}$. Z kolei o rozciagłłości przestrzeni albo o wielości liczb można mówić jedynie jako o czymś nieograniczonym, ponieważ nie są one bez granic pod wszelkimi względami²1. Umysł nie ujmuje czegoś, co ogranicza Boga, gdyż jest on poznawany pozytywnie jako pozbawiony granic, natomiast rzeczy nazywane nieograniczonymi są poznawane negatywnie, $\mathrm{w}$ tym sensie, że umysł nie może wykryć ich granic ${ }^{22}$. Idea nieskończoności jest ujmowana przez Kartezjusza jako kategoria metafizyczna, z kolei idea nieograniczoności jest kategorią poznawcza, gdyż wyraża się w stwierdzeniu, że ujęcie poznawcze w żadnym wypadku nie może osiągnąć granicy²3.

J. L. Wolzogen przyjmował stanowisko zgodne z tym prezentowanym przez przedstawicieli empiryzmu, ponieważ ujmował nieskończonośćjako coś negatywnego względem skończoności. Odnosząc się do przytoczonej odpowiedzi Kartezjusza zauważa, że nie ma wyraźnej różnicy między nieograniczonością a nieskończonością, podobnie jak nie ma różnicy między ślepcem a osobą pozbawioną wzroku. Przyjmuje, że umysł ma możliwość powiększania rozmaitych rzeczy, jednakże ta czynność nie jest nieskończona, lecz ma granicęe stopnia nie posiada się jej jasnego ujęcia. Gdy ktoś pomyśli, że jakiś obszar ma szerokość bilion albo nawet trylion razy większą od średnicy ziemi, to pomyśli jedynie o liczbie, ale nie będzie posiadał jasnej idei tego obszaru w umyśle. Według niego można pojąć, że przestrzeń wszechświata jest nieskończona, nie dzięki temu, że posiada się w umyśle jasną ideę nieskończonego wszechświata, ale dlatego, iż wyobrażając sobie granicę jakiejś przestrzeni można wykroczyć poza nią i ustanowić dalszą granicę i tę czynność przesuwania granicy powtarzać bezustannie ${ }^{25}$. Zdaniem J. L. Wolzogena idea wytworzona w ten sposób nie będzie przedstawiała nieskończoności, lecz jedynie pojmowanie myślowe (czynność przesuwania kresu $)^{26}$. Idea ta będzie skończona, podobnie jak czynność, w związku z tym idea aktualnie skończona nie może ukazywać bytu nieskończonego ${ }^{27}$.

J. L. Wolzogen nie mógł zgodzić się z koncepcją Kartezjusza, ponieważ prezentował odmienne stanowisko teoriopoznawcze ${ }^{28}$. Reprezentował aposterioryzm i uważał, że poznanie opiera się w głównej mierze na danych zmysłowych, z kolei zdaniem apriorysty Kartezjusza poznanie opiera się przede wszystkim na danych umysłowych ${ }^{29}$. J. L. Wolzogen ujmował nieskończoność negatywnie, ponieważ sądzil, że wszelkie informacje pochodzą ze zmysłów i na ich gruncie tworzy się pojęcia, podczas gdy Kartezjusz uznawał nieskończoność za pojęcie pozytywne, gdyż uważał, że źródło poznania znajduje się w samym rozumie ${ }^{30}$.

\section{RZECZYWISTOŚĆ OBIEKTYWNA I FORMALNA}

Kartezjusz dokonuje rozróżnienia między rzeczywistością obiektywną a formalną: gdy coś istnieje obiektywnie to oznacza, że istnieje tylko w myśli, natomiast to, co istnieje formalnie jest czymś istniejącym rzeczywiście ${ }^{31}$. Według niego rzeczywistość formalna idei, to idea rozważana w jej psychologicznym aspekcie jako kognitywny modus umysłu, natomiast rzeczywistość obiektywna idei, to idea ujęta pod względem reprezentatywnego charakteru jej zawartości ${ }^{32}$. Zgodnie z tym ujęciem idea w umyśle czerpie swą rzeczywistość formalną z myślenia, ponieważ stanowi modyfikacje myślenia, natomiast rzeczywistość obiektywna idei wymaga przyczyny, która zawiera

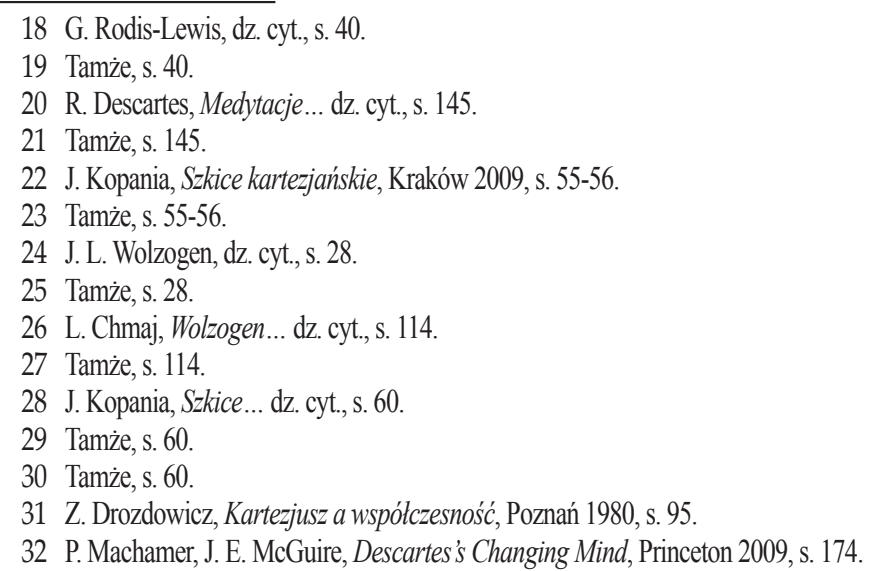


co najmniej tyle rzeczywistości formalnej, co idea rzeczywistości obiektywnej ${ }^{33}$. Zgodnie z zasadą przyjętą przez Kartezjusza rzeczywistość zawarta w skutku nie może być większa niż rzeczywistość zawarta w przyczynie, ponieważ owa nadwyżka rzeczywistości w skutku musiałaby mieć za swą przyczynę nicość, a to jest absurdalne ${ }^{34}$.

Kartezjusz zauważa, że idea Boga zawiera tak dużo rzeczywistości obiektywnej, że umysł nie może być jej przyczyna, gdyż nie zawiera aż tyle rzeczywistości formalnej. Dochodzi do wniosku, że idea Boga ma za swą przyczynę byt, który istnieje poza umysłem i posiada tyle rzeczywistości formalnej, co idea Boga rzeczywistości obiektywnej. Rzeczywistość obiektywna tkwiąca w idei jest zawsze mniej doskonała od rzeczywistości formalnej tkwiącej w pierwowzorze ${ }^{35}$. Rzeczywistość formalna danej rzeczy może przewyższać rzeczywistość obiektywną tkwiącą w idei tej rzeczy, ale nie może być od niej mniejsza, w związku z tym przyczyną idei Boga jest sam Bóg ${ }^{36}$.

J. L. Wolzogen w Uwwagach do Medytacji Metafizyczmych René Descartesa zwraca uwagę na to, że każda idea w umyśle jest obrazem i przez to jest czymś określonym i skończonym, a zatem nie tylko rzeczywistość obiektywna tkwiąca w idei jest zawsze skończona, lecz również rzeczywistość formalna tkwiąca w pierwowzorze jest skończona ${ }^{37}$. Na tej podstawie przyjmuje, że Bóg nie może być przyczynąidei Boga w umyśle. Zauważa również, że idee są odmianami (modyfikacjami) myślenia. Modyfikacje nie stanowią czegoś realnego i nie posiadają rzeczywistości, lecz jedynie modalnośćn ${ }^{38}$. Idee całą swą modalność biorą z myślenia i tym samym nie tylko rzeczywistość formalna, ale i rzeczywistość obiektywna idei ma za swą przyczynę myślenie ${ }^{39}$. W odniesieniu do tego twierdzi, że idea Boga swą rzeczywistość formalną i obiektywną czerpie z myślenia. Idea ta nie jest ideą rzeczy istniejącej rzeczywiście, lecz jest wytworzona przez umys ${ }^{\sharp 0}$. Według niego nieskończony Bóg nie może być przedstawiony przez żadną skończoną ideę w umyśle, ponieważ gdyby istniała idea rzeczywistego Boga byłaby nieskończona i niemożliwa do pojęcia przez ludzki umys ${ }^{41}$. Przyjmuje, że idea Boga, o której mówi Kartezjusz jest skończona i nie jest ideą rzeczywistego Boga.

J. L. Wolzogen nie był pierwszym filozofem, który zwrócił uwagę na wyżej wymieniony problem. Johannes Caterus w Zarzutach pierwszych zauważa, że idea posiadająca rzeczywistość obiektywną nie jest czymś istniejącym aktualnie. Przyczyna może udzielić jedynie bytu realnego i aktualnego, jeśli natomiast coś nie istnieje aktualnie, nie otrzymuje działania tej przyczyny, a zatem idea nie ma przyczyny poza umysłem ${ }^{42}$. Kartezjusz zgadzał się z J. Caterusem, że idea w umyśle nie istnieje aktualnie, ale nie zgadzał się z tym, że idea nie domaga się przyczyny istniejącej poza intelektem, ponieważ gdy pojmujemy jakąś ideę musimy wskazać przyczynę tego, że jest ona pojmowana ${ }^{43}$. Zauważa, że gdy rozważamy ideę maszyny nie wystarczy wskazać, że idea ta ma za swą przyczynę formalną intelekt, ponieważ trzeba również wskazać przyczynę obiektywnego kunsztu tej idei (przyczyną tą może być np. kunszt tkwiący formalnie w umyśle inżyniera) ${ }^{44}$. Według niego, to samo dotyczy idei Boga. Rzeczywistość obiektywna tkwiąca w tej idei musi mieć przyczynę. Wszelka doskonałość znajdująca się w idei Boga domaga się przyczyny, w której cała ta doskonałość zawarta jest formalnie, w związku z tym przyczyną tą może być jedynie rzeczywisty Bóg 45 .

J. L. Wolzogen nie akceptował wniosku Kartezjusza, że idea Boga ma za swą przyczynę rzeczywistego Boga, ponieważ przyjmował, że idea ta nie jest ideą bytu istniejącego rzeczywiście, lecz ideą skonstruowaną przez umysł. Jest ona tak samo skończona i ograniczona jak wszystkie inne idee w umyśle. Nie negował tego, że Bóg istnieje, ponieważ przyznawał, że zdolność, dzięki której umysł może utworzyć ideę Boga musi pochodzić od Stwórcy, jednakże zaprzeczał temu, iż Bóg jest bezpośrednią przyczyną tej idei.

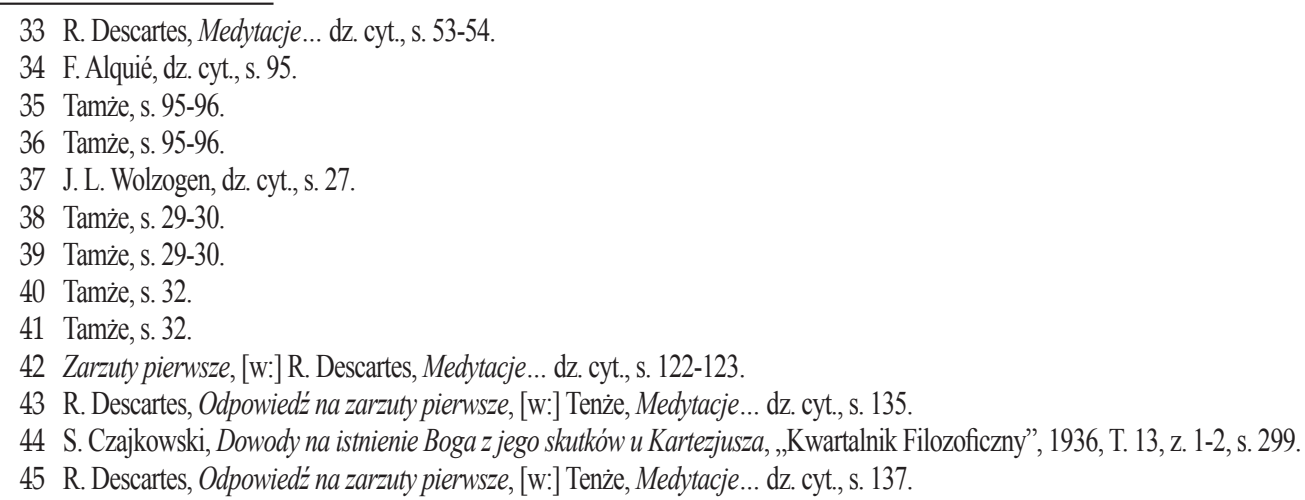




\section{Problem pochodzenia idei Boga w ujęciu Kartezjusza}

Kartezjusz doszedł do wniosku, że idea bytu nieskończonego ma za swą przyczynę rzeczywistego Boga, a następnie stanął przed koniecznością rozstrzygnięcia następującego problemu: w jaki sposób idea ta znalazła się w jego umyśle?". Zagadnienie to rozważa pod koniec Medytacji III. Zauważa, że idea Boga nie przyszła do niego dzięki poznaniu zmysłowemu, nie może być również ideą utworzona, ponieważ w żaden sposób nie można do niej niczego dodać ani z niej odją́c' ${ }^{\prime 7}$. Kartezjusz odrzuca również nadnaturalne pochodzenie tej idei; nie można przyjąć, że idea ta przyszła do umysłu dzięki Bożemu objawieniu, ponieważ wówczas musiałaby znaleźć się w umyśle dzięki zmysłom, a to jest wykluczone ${ }^{48}$. Należy zatem przyjąć, że idea Boga jest wrodzona. Idea ta, podobnie jak idee figur i liczb nie jest czymś co narzuca się umysłowi, dlatego wielu ludzi w ogóle jej sobie nie uświadamia ${ }^{49}$. Zdaniem Kartezjusza nie należy sądzić, że nowonarodzone dziecko ma aktualne pojęcie Boga, gdyż wrodzoność idei Boga oznacza, że w umyśle tkwi potencjalna zdolność umożliwiająca poznanie idei Boga niezależnie od doświadczenia zmysłowego ${ }^{50}$. Innymi słowy umysł dzięki własnym zdolnościom odkrywa ideę Boga w samym sobie. Tkwi w umyśle potencjalnie od momentu jego stworzenia. Koncepcję Kartezjusza określa się mianem dyspozycyjnej teorii idei wrodzonych, ponieważ to, że idea jest wrodzona nie oznacza, że umysł zawsze jest jej świadomy, lecz umysł ma naturalną zdolność pozwalającą mu przywołać tę ideę". Należy uznać, że podobnie jak artysta pozostawia znak na swym dziele, tak Bóg zaszczepił w umyśle tę ideę, w związku z tym znaknie jest czymś innym niż samo dzieło ${ }^{52}$. Kartezjusz zauważa, że został stworzony na podobieństwo Boga i idea, którą Bóg w nim zaszczepił zawiera całe podobieństwo w sobie. Autor Medytacji o pierwszej filozofii może w jednym ujęciu pojąć Boga jako byt nieskończony i siebie samego jako byt skończony ${ }^{53}$. Innymi słowy, gdy skieruje uwagę na siebie dostrzega swą ograniczoność i zależność od czegoś większego. Pojmuje, że jest czymś, co stale dąży do czegoś większego, ale równocześnie ujmuje nieskończony byt, od którego jest zależny i który posiada wszystkie doskonałości rzeczywiście ${ }^{54}$.

Może się wydawać czymś zaskakującym, że ograniczony i skończony umysł jest zdolny wygenerować ideę bytu nieskończonego ${ }^{55}$. Jeśli przyjmie się, że idea Boga jest wrodzona, to wówczas musi być wygenerowana przez formalną rzeczywistość podmiotu myślącego, a przecież rzeczywistość zawarta w idei Boga przewyższa rzeczywistość podmiotu myślącego ${ }^{56}$. Jednakże należy zauważyć, że Bóg zaszczepił tę ideę w podmiocie myślącym i dał mu moc, dzięki której podmiot może wygenerować tę ideę $e^{57}$.

Kartezjusz zauważa, że idea Boga jest jasna i wyraźna, jednakże on, jako byt skończony, nie może ogarnąć rzeczy nieskończonej; wiele jest rzeczy w Bogu, których skończony umysł nie może pojąć, gdyż to przekracza jego możliwości58. Według niego nie jest niczym niezwykłym, że możemy posiadać ideę Boga, która jest jasna i wyraźna i jednocześnie nie ogarniać wszystkich przymiotów bytu nieskończonego. Kartezjusz wyjaśnia tę kwestie posługując się następującym przykładem: nie możemy objąć wzrokiem całego morza, jednakże możemy skupić się na jego fragmencie i ująć go jasno i wyraźnie. Podobnie nie możemy pojąć adekwatnie bytu nieskończonego, jednakże to, co pojmujemy o Bogu wystarcza do tego, aby było poznawane jasno i wyraźni ${ }^{59}$.

Wniosek, jaki się nasuwa, wskazuje, że Bóg w filozofii Kartezjusza nie jest już Bogiem religii, z którym człowiek zachowuje personalny kontakt, lecz staje się Bogiem filozofii umożliwiającym skończonemu umysłowi działanie w sferze nauki ${ }^{60}$. Bezpośredniość relacji między człowiekiem a Bogiem została zastąiona przez znak zaszczepiony w umyśle;

46 W. Augustyn, dz. cyt., s. 93.

47 R. Descartes, Medytacje... dz. cyt., s. 67.

48 J. Kopania, Funkcje poznawcze Descartesa teorii idei, Białystok 1988, s. 130-131.

49 Tamże, s. 132.

50 F. Copleston, Historia filozofii, T. 2, Warszawa 2000, s. 104.

51 L. Nolan, The Third Meditation: causal arguments for God's existence, [w:] D. Cunning, The Cambridge Companion to Descartes'Meditations, Cambridge 2014, s. 131.

52 R. Descartes, Medytacje... dz. cyt., s. 67.

53 Tamże, s. 68.

54 Tamże, s. 68.

55 S. I. Wagner, Squaring the Circle in Descartes'Meditations, Cambridge 2014, s. 175.

56 Tamże, s. 175.

57 Tamże, s. 175.

58 R. Descartes, Medytacje... dz. cyt., s. 60-61.

59 R. Descartes, Odpowiedź na zarzuty pierwsze, [w:] Tenże, Medytacje... dz. cyt., s. 146-147. Tenże, Odpowiedź na zarzuty drugie, [w:] Tenże, Medytacje... dz. cyt., s. 190.

60 T. Śliwiński, Religijność Kartezjusza, czyli o ostatecznym Testamencie Boga, http:/www.nowakrytyka.pl/spip.php?article393, 15.11.2014. 
miejsce Boga religii zajął Bóg wiedzy, z którym nie wiąże się emocjonalne zaangażowanie ${ }^{61}$. Kartezjusz przyczynił się do rozdzielenia sfery wiary i wiedzy, w jego filozofii rozum stał się samowystarczalny i mógł sobie radzić bez odwoływania się do objawienia ${ }^{62}$. Umysł sam o własnych siłach odkrywa w sobie ideę Boga, nie musi odwoływać się do doświadczenia zmysłowego, aby wiedzieć o tym, że Bóg istnieje. W metafizyce Kartezjusza Bóg odgrywa istotną rolę, ponieważ jest zasada, która stworzyła świat i utrzymuje go w istnieniu, jednakże nie ma żadnego znaczenia w wyjaśnianiu pojedynczych zjawisk natury (można badać prawa rządzące przyrodą nie biorąc pod uwagę istnienia Boga) ${ }^{63}$.

\section{WOLZOGENA KRYTYKA WRODZONOŚCI IDEI BOGA}

Główne zarzuty przeciwko wrodzoności idei Boga przedstawili Kartezjuszowi autorzy Zarzutów drugich oraz Pierre Gassendi: nawiązywali do stanowiska Tomasza z Akwinu, zgodnie z którym nikt nie posiada w umyśle wrodzonej idei Boga, a jedynie pojęcie ukształtowane za pomocą idealizacji albo analogii ${ }^{64}$. Autorzy Zarzutów drugich zwracają uwagę na to, że idea Boga tworzona jest z doskonałości ujmowanych w rzeczach skończonych ${ }^{65}$. Dodając do siebie kolejne doskonałości bytów skończonych można utworzyć ideę bytu, który zawierałby wszystkie te doskonałości6 ${ }^{6}$. Według nich idea ta jest jedynie bytem myślowym i nie jest czymś doskonalszym od samego umysłu, który ją utworzył. Idea Boga powstała dzięki rozmyślaniom umysłu, rozmowom z innymi ludźmi oraz wiedzy zaczerpniętej z książek ${ }^{67}$.

Krytyka P. Gassendiego jest znacznie bardziej rozbudowana od krytyki autorów Zarzutów drugich. Zgodnie z jego koncepcją ideę Boga ukształtowaliśmy dzięki idealizacji kolektywnej, a nie jednostkowej68. Umysł składa w jedno wszelkie możliwe doskonałości poznawane w innych stworzeniach i rozciąga je do możliwie najdalszych granic (np. rozszerza trwanie, moc, wiedzę i tworzy pojęcie Boga wiecznego, wszechmocnego i wszechwiedzącego $)^{69}$. Według niego posiadamy jedynie ideę Boga skonstruowaną dla własnego użytku, która w żaden sposób nie przekracza pojętności umysłu i nie przewyższa swą rzeczywistością tej zawartej w rzeczach skończonych ${ }^{70}$. Zdaniem P. Gassendiego nie powinniśmy sądzić, że skonstruowana przez umysł idea Boga przedstawia istotę rzeczywistego Boga, ponieważ doskonałości Boga nie mogą w żaden sposób być porównywane z doskonałościami rzeczy skończonych ${ }^{71}$.Zgodnie zjego poglądem idea ta nie została zaszczepiona przez Boga w umyśle, lecz powstała dzięki rozważaniom nad przedmiotami zmysłowymi ${ }^{72}$. Innymi słowy została ukształtowana na podstawie danych pochodzących ze zmysłów i nie ma w sobie niczego jasnego i wyraźnego ${ }^{73}$. Jego zdaniem rzeczywistego Boga nikt nie jest w stanie pojąć, gdyż przekracza to możliwości umysłu".

J. L. Wolzogen w dziele Uwagi do Medytacji Metafizycznych René Descartesa przedstawia argumenty przeciwko wrodzoności idei Boga, w dużej mierze nawiązujące do zarzutów P. Gassendiego. Skupia się na wykazaniu, że Kartezjusz zbyt pochopnie uznat, iż idea Boga nie pochodzi od zmysłów ani nie jest utworzona. Nawet jeśli autor Medytacji o pierwszej filozofii przyjął, że wszystko, co dotychczas otrzymał od zmysłów jest złudzeniem, to nie mógł tym sposobem wymazać z pamięci wiedzy zaczerpniętej ze zmysłów, a więc nie może wykluczyć, że idei Boga nie utworzył dzięki tej wiedzy ${ }^{75}$. J. L. Wolzogen zauważa, że gdyby Kartezjusz od chwili narodzin nie posiadał żadnych wrażeń zmysłowych, to nie mógłby posiadać tej wiedzy o Bogu, którą ukazał w Medytacjach o pierwszej filozofii. Kartezjusz przypisuje Bogu wszechmoc, wszechwiedzę oraz inne przymioty, ponieważ dowiedział się o nich dzięki doświadczeniu zmysłowemu ${ }^{76}$. J. L. Wolzogen, podobnie jak autorzy Zarzutów drugich uważa, że idea Boga w umyśle jest kształtowana dzięki dyskusjom z innymi ludźmi, czy też przeczytanym książkom, a zatem jest to wiedza zaczerpnięta tylko i wyłącznie ze zmysłów. Poddaje krytyce słowa Kartezjusza o tym, że idea Boga nie jest utworzona, ponieważ niczego do niej dodać nie można i niczego

61 Tamże.

62 L. Kołakowski, Iluzje demitologizacji... dz. cyt., s. 68.

63 Tamże, s. 68

64 S. Czajkowski, dz. cyt., s. 303.

65 Tamże, s. 303.

66 Tamże, s. 303.

67 Zarzuty drugie, [w:] R. Descartes, Medytacje... dz. cyt., s. 157.

68 S. Czajkowski, dz. cyt., s. 304.

69 Tamże, s. 304.

70 R. Descartes, Medytacje... dz. cyt., s. 340.

71 Tamże, s. 340.

72 S. Czajkowski, dz. cyt., s. 305.

73 Tamże, s. 305.

74 Tamże, s. 306.

75 J. L. Wolzogen, dz. cyt., s. 44.

76 Tamże, s. 44. 
z niej ująć. Zauważa, że autor Medytacji o pierwszej filozofii z pewnością nie wie wszystkiego o Bogu, a zatem nie może wykluczyć, że mogą istnieć ludzie lub jakieś istoty niebiańskie, które mają możliwość przekazania mu informacji o Bogu, o których nie miał żadnego pojęcia ${ }^{7}$. Z pewnością informacje nabyte dzięki objawieniu poszerzyłyby jego wiedzę o Bogu i dlatego nie jest prawda, że niczego do tej idei nie można już dodać. Mógłby się również dowiedzieć, że fałszywie przypisywał jakieś cechy Bogu, w takiej sytuacji musiałby coś ująć ze swej idei Boga. Poza tym należy zauważyć, że umysł ludzki nie jest w stanie pojąć wielu rzeczy ze świata przyrody, nie może posiąść pełnej wiedzy o istocie maleńkiej muchy, nie jest zatem niczym niezwykłym, że dla umysłu istota Boga jest niepojęta ${ }^{78}$. Według niego nieprzeniknioną tajemnicą okryta jest niezliczona ilość atrybutów Boga i sam umysł bez pomocy objawienia nie może ich odkryćc ${ }^{\prime 7}$.

J. L. Wolzogen, tak jak P. Gassendi uważa, że intelekt tworzy ideę Boga, ponieważ posiada możliwość rozszerzania ujmowanych doskonałości, takich jak trwanie, ilość, jakość itd., jednakże zdolności intelektu są ograniczone i dlatego rozszerzanie nie może trwać w nieskończonośc ${ }^{80}$. Zgodnie z tą koncepcją umysł nigdy nie będzie w stanie pojąć pozytywnej idei rzeczy nieskończonej, gdyż przekracza to jego możliwości poznawcze. J. L. Wolzogen nie wątpi w to, że Bóg udzielił człowiekowi zdolności, dzięki której może on utworzyć ideę Boga na podstawie doświadczenia zmysłowego, jednakże nie może się zgodzić z tym, iż Bóg jest bezpośrednią przyczyną tej idei w umyśle ${ }^{81}$.

J. L. Wolzogen dostrzega w koncepcji Kartezjusza zagrożenie dla objawienia. Skoro idea Boga zawarta w umyśle jest kompletna i niczego do niej dodać nie można, to objawienie staje się zbędne. Innymi słowy, jeśli przyjmie się, że umysł posiada w sobie wrodzoną wiedzę dotyczącą Boga, to nie trzeba odwoływać się do objawienia. W filozofii Kartezjusza skończony rozum objął sferę zagadnień dotyczących Boga i rozważał je nie biorąc pod uwagę autorytetu kościoła i tradycji ${ }^{82}$. J. L. Wolzogen dostrzegł, że w racjonalizmie kartezjańskim znajdowały się elementy, które mogły dać początek racjonalizmowi absolutnemu, a taki racjonalizm zastępował autorytet objawienia w religii autorytetem rozumu ${ }^{83}$.

\section{Próba odparcia zarzutów Przez Kartezjusza}

W odpowiedzi na Zarzuty drugie Kartezjusz stwierdza, że idei Boga nie powinno się nazywać bytem myślowym, ponieważ bytem myślowym określa się wytwór intelektu, który nie istnieje rzeczywiście, a idea Boga ma za przyczynę rzeczywisty byt ${ }^{84}$. Kartezjusz zauważa, że ci, którzy próbują utworzyć sobie ideę Boga za pomocą wyobraźni, mogą utworzyć jedynie urojone wyobrażenie Boga zawierające liczne sprzeczności, nie jest zatem niczym niezwykłym, że ateiści na podstawie tego urojonego pojęcia wnioskują o nieistnieniu Boga ${ }^{85}$. Autor Medytacji o pierwszej filozofii przyjmuje, że idea Boga nie ma takiej samej natury jak rzeczy ujmowane za pomocą wyobraźni, lecz jest tylko tym, co można ująć samym intelektem ${ }^{86}$. Przyjmuje, że idea Boga jest rozumowa i nie jest urobiona, ponieważ idee urobione mogą być poddawane różnorakim modyfikacjom, natomiast idea rzeczywistego Boga narzuca się umysłowi w sposób jednoznaczny ${ }^{87}$. Natura tej idei nie dopuszcza możliwości jakichkolwiek zmian, ponieważ gdyby mogła się zmienić, to nie byłaby ideą Boga ${ }^{88}$. Według niego koncepcja zakładająca, że idea Boga powstała w umyśle dzięki rozmowom prowadzonym zinnymi ludźmi i przeczytanym książkom nie jest przekonująca, gdyż należy zapytać skąd wzięła się idea Boga w rzeczach, od których umysł otrzymał tą ideę? ${ }^{89}$. Zdaniem autora Medytacji o pierwszej filozofii odpowiedź może być tylko jedna, idea tkwiąca w tych rzeczach pochodzi od samego Boga.

Według niego nie można sądzić, że ideę Boga tworzymy poprzez rozszerzanie dostrzeżonych doskonałości. Idea ta jest pierwotna i bez niej umysł nie mógłby rozszerzać dostrzeganych w naturze doskonałości90. Umysł dzięki niej uświa-

77 Tamże, s. 44

78 Tamże, s. 44-45.

79 Tamże, s. 45.

80 Tamże, s. 35.

81 L. Chmaj, Wolzogen ... dz. cyt., s. 118.

82 Z. Ogonowski, Socynianizm polski, Warszawa 1960, s. 59.

83 Tamże, s. 59.

84 R. Descartes, Odpowiedź na zarzuty drugie, [w:] Tenże, Medytacje... dz. cyt., s. 170.

85 S. Czajkowski, dz. cyt., s. 307.

86 R. Descartes, Odpowiedź na zarzuty drugie, [w:] Tenże, Medytacje... dz. cyt., s. 175.

87 S. Czajkowski, dz. cyt., s. 307.

88 Tamże, s. 307.

89 R. Descartes, Odpowiedź na zarzuty drugie, [w:] Tenże, Medytacje... dz. cyt., s. 172.

90 S. Czajkowski, dz. cyt., s. 308. 
damia sobie własne ograniczenia, ujmuje byt doskonalszy od siebie, nie zawierający żadnych braków ${ }^{91}$. Innymi słowy umysł pojmuje, że ujmowane doskonałości są ograniczone i mogą być rozszerzone jeszcze bardziej, ponieważ posiada ideę Boga, czyli bytu przewyższającego wszystkie te doskonałości92. Zgodnie z tym idea Boga nie jest kształtowana za pomocą procesu myślowego. Zdaniem Kartezjusza należy odrzucić koncepcję Tomasza z Akwinu i P. Gassendiego głosząca, że idea Boga powstaje na drodze idealizacji, gdyż idea ta jest dana od razu i nie dopuszcza żadnych zmian³. P. Gassendi przyjmował, że Bóg byłby czymś niedoskonałym, gdyby był w rzeczywistości taki, jakim go pojmuje skończony umysł, natomiast Kartezjusz nie zgadzał się z tym i twierdził, że umysł ujmuje Boga jako nieskończony byt, a nic nie może przewyższać nieskończonego bytu ${ }^{94}$ P. Gassendi zwraca Kartezjuszowi uwagę na to, że umysł ludzki nie jest w stanie pojąć nieskończoności ${ }^{95}$. A zatem, gdy umysł określa coś jako nieskończone, to tak naprawdę nie rozumie czym jest nieskończonośćc ${ }^{96}$. W odpowiedzi na ten zarzut autor Medytacji o pierwszej filozofii stwierdził, że P. Gassendi myli wyobrażanie z pojmowaniem intelektualnym ${ }^{97}$. Według niego należy dokonać rozróżnienia między poznaniem umysłowym rzeczy dostosowanym do naszych możliwości, dzięki któremu pojmujemy to, co nieskończone, a adekwatnym pojmowaniem rzeczy, którego umysł ludzki nie posiada i dlatego nie może ujać adekwatnie idei nieskończonościp ${ }^{98}$ Zgodnie z tym należy przyjąć, że pojmujemy czym jest nieskończoność, jednak nie jest to pojęcie adekwatne.

\section{ZAKOŃCZENIE}

Zarzuty J. L. Wolzogena skierowane przeciwko wrodzoności idei Boga częściowo powielały argumenty P. Gassendiego. Autor Uwwag do Medytacji Metafizycznych René Descartesa przyjmował pogląd, zgodnie z którym wszelka wiedza pochodzi z doświadczenia zmysłowego i dlatego nie mogą istnieć idee wrodzone. Ludzki umysł nie jest w stanie pojąć pozytywnej idei nieskończoności, może jedynie utworzyć ideę nieskończoności na drodze negatywnej poprzez zaprzeczenie tego, co skończone. Stanowisko przyjmujące pierwszeństwo idei skończoności przed ideą nieskończoności było przyjmowane przez większość empirystów. W przeciwieństwie do nich racjonaliści uważali, że idea nieskończoności jest pierwotna, a idea skończoności wtórna.

Zdaniem Kartezjusza umysł posiada ideę bytu nieskończonego i na tle tej idei ujmuje wszystkie byty skończone. Rozważając problem pochodzenia idei bytu nieskończonego w umyśle doszedł do wniosku, że idea ta jest wrodzona i została zaszczepiona przez samego Boga. Uznał, że idea Boga nie podlega żadnym modyfikacjom, nie można do niej niczego dodać ani z niej ująć, ponieważ jest kompletna. Z tym nie mógł się zgodzićJ. L. Wolzogen, który uważał, że nie posiadamy w umyśle idei przedstawiającej rzeczywistego Boga, a jedynie pojęcie urobione przez umysł.

J. L. Wolzogen przeciwstawiał się koncepcji Kartezjusza nie tylko dlatego, że prezentował odmienne poglądy epistemologiczne. Głównym powodem był fakt, że pogląd autora Medytacji o pierwszej filozofii zagrażał wierze w objawienie. Według J. L. Wolzogena, jeśli przyjmiemy, że umysł posiada wrodzoną ideę przedstawiającą rzeczywistego Boga, to odwoływanie się do pomocy objawienia staje się zbędne. Innymi słowy rozum, który o własnych siłach niezależnie od doświadczenia zmysłowego odkrywa istnienie Boga, może wyprowadzić sam z siebie wiedzę dotyczącą Boga i nie musi brać pod uwagę objawienia Bożego. Zdaniem J. L. Wolzogena filozofia kartezjańska zakłada, że dowód na istnienie Boga pochodzi z samego rozumu, natomiast objawienie nie może stanowić gwarancji tego, że Bóg istnieje ${ }^{99}$. Wysłani przez Boga posłańcy nie mogą dostarczyć dowodów potwierdzających istnienie Boga, ponieważ zgodnie z poglądem Kartezjusza wszystko, co trafia do umysłu przez wrażenia zmysłowe jest niepewne ${ }^{100}$. W związku z tym J. L. Wolzogen podkreślał, że Kartezjusz nie miał racji, ponieważ wiedza człowieka jest ograniczona i skończony rozum nie może mieć doskonałej idei Boga. Jego zdaniem wiedzę o Bogu czerpiemy z objawienia zawartego w Piśmie Świętym i nie można dowieść za pomocą argumentów rozumowych istnienia Boga. Przyjmował stanowisko sensualizmu w teorii poznania, ponieważ sądził, że

\footnotetext{
91 Tamże, s. 308.

92 R. Descartes, Odpowiedź na zarzuty piąte, [w:] Tenże, Medytacje... dz. cyt., s. 430.

93 S. Czajkowski, dz. cyt., s. 308.

94 R. Descartes, Odpowiedź na zarzuty piąte, [w:] Tenże, Medytacje... dz. cyt., s. 430.

95 L. Chmaj, Wolzogen ... dz. cyt., s. 115.

96 Tamże, s. 115.

97 Tamże, s. 115.

98 R. Descartes, Odpowiedź na zarzuty piąte, [w:] Tenże, Medytacje... dz. cyt., s. 429.

99 L. Kołakowski, Świadomość religijna i więź kościelna. Studia nad chrześcijaństwem bezwyznaniowym XVII wieku, Warszawa 1997, s. 180.

100 Tamże, s. 180.
} 
jest to pogląd niezagrażający wierze w objawienie ${ }^{101}$. Sensualizm J. L. Wolzogena ograniczał rozważania umysłu do sfery danych doświadczenia zmysłowego, a wszelkie spekulacje wykraczające poza te dane uważał za pozbawione sensu ${ }^{102}$.

Należy wyraźnie podkreślić, że Kartezjusz nie negował wiary w objawienie, przyjmował, że wiara stanowi akt woli, a nie umysłu i należy wierzyć, że objawienie Boże jest pewniejsze od wszelkiego poznania ${ }^{103}$. Jednakże nie zmienia to faktu, że filozofia Kartezjusza stała się podłożem nowożytnego deizmu, który odrzucił objawienie i uznał Boga jedynie za stwórcę świata nie ingerującego w rzeczywistośćc ${ }^{104}$. Kartezjusz przyjmował, że rzeczywistość fizyczna podlega niezmiennym prawom i można badać zjawiska fizyczne nie biorąc pod uwagę istnienia Boga ${ }^{105}$. Przyczynił się tym samym do zatracenia możliwości dostrzegania znaków Boga w przyrodzie ${ }^{106}$. Filozofia Kartezjańska zastąpiła organiczne postrzeganie świata przyrody koncepcją mechanistyczna, jedną z konsekwencji wynikających z tego faktu było sprowadzenie zwierząt do roli automatów ${ }^{107}$.

Kartezjusz oddzielił sferę rozumu od sfery wiary i przez to spowodował, że rozum stał się autonomiczny i mógł zdobywać pewną wiedzę o rzeczywistości niezależnie od objawienia ${ }^{108}$. Wprowadził podział między Boga rozumu a Boga wiary, przy czym nadał szczególną rangę pierwszemu, podczas gdy rolę drugiego zmarginalizował1 ${ }^{109}$. Z tego też powodu obawy J. L. Wolzogena były uzasadnione. Autor Uwwag do Medytacji Metafizycznych René Descartesa słusznie zwrócił uwagę na te elementy w filozofii Kartezjusza, które mogły stać się podstawą do powstania deizmu i wyrugowania objawienia $\mathrm{z}$ religii.

\title{
Bibliografia:
}

[1] Alquié F., Kartezjusz, Warszawa 1989

[2] Augustyn W., Podstawy wiedzy u Descartesa i Malebranche'a, Warszawa 1973

[3] Chmaj L., Wolzogen przeciw Descartes'owi: przyczynek do charakterystyki zwiazku arianizmu polskiego z myśla filozoficzną Zachodu, „Archiwum Komisji do Badania Historii Filozofii w Polsce"1915, T. 1, cz. 1

[4] Copleston F., Historia filozofii, T. 2, Warszawa 2000

[5] Czajkowski S., Dowody na istnienie Boga z jego skutków u Kartezjusza, „Kwartalnik Filozoficzny”, 1936, T. 13, z. 1-2

[6] Descartes R., Medytacje o pierwszej filozofii wraz z zarzutami uczonych męźów i odpowiedziami autora oraz rozmowa z Burmanem, T. 1, Warszawa 1958

[7] Descartes R., Prawidla kierowania umystem, Poszukiwanie prawdy poprzez światto przyrodzone rozumu, Warszawa 1958

[8] Drozdowicz Z., Bóg w filozofii Kartezjusza, [w:] Janeczek S. (red.), Oblicza filozofii XVII wieku, Lublin 2008

[9] Drozdowicz Z., Kartezjusz a wspótczesność, Poznań 1980

[10] Kołakowski L., Iluzje demitologizacji, [w:] Tenże, Moje stuszne poglady na wszystko, Kraków 1999

[11] Kołakowski L., Świadomość religijna i więź kościelna. Studia nad chrześcijaństwem bezwyznaniowym XVII wieku, Warszawa 1997

[12] Kopania J., Funkcje poznawcze Descartesa teorii idei, Białystok 1988

[13] Kopania J., Szkice kartezjańskie, Kraków 2009

[14] Machamer P., McGuire J. E., Descartes's Changing Mind, Princeton 2009

[15] Nolan L., The Third Meditation: causal arguments for God's existence, [w:] D. Cunning, The Cambridge Companion to Descartes' Meditations, Cambridge 2014

[16] Ogonowski Z., Socynianizm a oświecenie, Warszawa 1966

[17] Ogonowski Z, Socynianizm polski, Warszawa 1960

[18] Rodis-Lewis G., Kartezjusz i racjonalizm, Warszawa 2000

[19] Wagner S. I., Squaring the Circle in Descartes' Meditations, Cambridge 2014

[20] Wasik W., Kartezjusz w Polsce, „Przegląd Filozoficzny” 1937, r. 40, z. 2

[21] Wolzogen J. L., Uwwagi do Medytacji Metafizycznych René Descartes'a, Warszawa 1959

\section{Netografia:}

[22] Kołakowski L., O rozumie i innych rzeczach, www.tygodnik.onet.pl/zmysły/o-rozumie-i-innych-rzeczach/f3lhb, 28.10 .2014

[23] Śliwiński T., Religijność Kartezjusza, czyli o ostatecznym Testamencie Boga, http://www.nowakrytyka.pl/spip.php?article393, 15.11.2014

\author{
101 L. Chmaj, Wolzogen ... dz. cyt., s. 124. \\ 102 Tamże, s. 124. \\ 103 R. Descartes, Prawidła kierowania umystem, Poszukiwanie prawdy poprzez światto przyrodzone rozumu, Warszawa 1958, s. 14. \\ 104 L. Kołakowski, Iluzje demitologizacji... dz. cyt., s. 68. \\ 105 Tenże, O rozumie i innych rzeczach, www.tygodnik.onet.pl/zmysły/o-rozumie-i-innych-rzeczach/f3lhb, 28.10.2014. \\ 106 Tamże. \\ 107 Tamże. \\ 108 Tenże, Iluzje demitologizacji... dz. cyt., s. 68. \\ 109 Z. Drozdowicz, Bóg w filozofi Kartezjusza, [w:] S. Janeczek (red.), Oblicza filozofii XVII wieku, Lublin 2008, s. 41.
}

